\title{
Õpetaja professionaalse rolli internaliseerimise hindamine õpetajakoolituse esmaõppe üliõpilaste hulgas
}

\author{
Äli Leijen ${ }^{a b 1}$, Katrin Kullasepp ${ }^{c}$, Aivar Ots ${ }^{a c}$ \\ ${ }^{a}$ Tartu Ülikooli haridusteaduste instituut \\ b Tartu Ülikooli Viljandi kultuuriakadeemia \\ ${ }^{c}$ Tallinna Ülikooli psühholoogia instituut
}

\begin{abstract}
Annotatsioon
Artiklis tutvustatakse õpetaja professionaalse rolli internaliseerimise uurimiseks loodud testi. Õpetaja professionaalse identiteedi kujunemist võib käsitleda vastava sotsiaalse rolli internaliseerimisena, mis võib leida aset ainult sotsiokultuurilises kontekstis, pakkudes personaalse kultuuri loomiseks semiootiliselt vahendatud teavet (Valsiner \& Rosa, 2007). Semiootilise materjali vahendamist isiku ja keskkonna vahel saab kirjeldada internaliseerimise ja eksternaliseerimisena (Valsiner, 2001). Kirjeldatava testi puhul kasutati isiku ja keskkonna dialoogi mõtestamiseks intrapsüühilisel tasandil dialoogilise mina teooriat (Hermans \& Hermans-Konopka, 2010), mis võimaldab jälgida isiku aktuaalseid rolle, nende seoseid ja muutumist.

Tutvustatava testi koostamisel tugineti Kullasepa (2008) ning Leijeni ja Kullasepa (2013a) loodud mõõtevahenditele. Test koosneb üheksast ülesandest, kus vastajal tuleb õpetajatööga seotud dilemma kirjelduse põhjal nimetada ja seletada vastavas olukorras tekkivaid tundeid.

Uuringus osales 109 õpetajakoolituse üliõpilast. Eeldati, et õpetajakoolituses kaugemale jõudnud ja suurema pedagoogilise töö kogemusega isikute vastused väljendavad enam professionaalse rolli omaksvõtmist. Tulemused kinnitasid nimetatud seost töökogemuse ja professionaalse rolli omaksvõtmise vahel. Suurema töökogemusega üliõpilaste vastused kajastasid teistega võrreldes sagedamini internaliseeritud professionaalset mina-positsiooni.
\end{abstract}

Võtmesõnad: õpetaja professionaalne identiteet, õpetajakoolitus, rolli internaliseerimine, aineõpetaja, dialoogilise mina teooria, sotsiokultuuriline käsitlus

Haridusteaduste instituut, sotsiaal- ja haridusteaduskond, Tartu Ülikool, Salme 1a, 50103 Tartu, ali.leijen@ut.ee 


\section{Sissejuhatus}

Õpetajate töö, õppimise ja arengu uurimine on viimase kahekümne aasta jooksul oluliselt muutunud (vt ülevaadet Akkerman \& Meijer, 2011). Peale õpetajatööga seotud erialaste teadmiste ja oskuste omandamise ning asjakohaste hoiakute kujundamise on järjest olulisemaks muutunud ka õpetaja isiksuseomadused erialase tegevuse kontekstis. Professionaalne identiteet tähendab üldiselt võetuna seda, kuidas ennast ametialaselt määratletakse (Beijaard, Meijer, \& Verloop, 2004). Professionaalne identiteet kujuneb indiviidi ja sotsiokultuurilise keskkonna dialoogi kaudu, mille käigus internaliseeritakse sotsiaalse (professionaalse) rolliga seotud ootused ning ehitatakse üles isikupärane professionaalne mina-tunnetus (nt „mina kui õpetaja”) (Valsiner, 2001, 2007; täpsem kirjeldus järgmises alapeatükis). Professionaalset rolli määratletakse siinse uurimuse raames kui institutsionaalselt (nt õppekavas sisalduvad institutsionaalsed regulatsioonid) ja subjektiivselt konstrueeritud ootuste kogumit, mis internaliseerudes saab potentsiaali kujundada isiku reageeringuid erinevates, sh professionaalsetes, kontekstides.

Mitmed oppetajakoolituse uurijad on osutanud nii Eestis (vt nt Anspal, Eisenschmidt, \& Löfström, 2012; Löfström, Poom-Valickis, Hannula, \& Mathews, 2010; Timoštšuk \& Ugaste, 2010, 2012) kui ka mujal läbi viidud uuringute põhjal (vt nt Beijaard, 1995; Kelchtermans, 2009; Korthagen \& Vasalos, 2005), et ülikoolides on vaja varasemast rohkem toetada õpetajakoolituse üliõpilaste professionaalse identiteedi kujunemist, sest õpetaja professionaalne enesemääratlus on seotud mitmete ametialase efektiivsusega seotud tunnustega, nagu töörahulolu, erialane pühendumus, enesetõhusus ja motivatsioon (Day, 2002). Samas on mitmed autorid (nt Bohl \& van Zoest, 2002; Danielewicz, 2001; Grossman \& McDonald, 2008) osutanud, et õpetajakoolituse üliõpilaste professionaalse identiteedi kujunemist ei toetata ülikoolide õpetajakoolituse õppekavades piisavalt. Alsup (2006) ja Danielewicz (2001) on näidanud, et professionaalse ja personaalse identiteedi kooskõla on seotud sellega, kui edukas on õpetajaametisse sisseelamine. Need uurimused kinnitavad, kui oluline on mõista õpetajakoolituse üliõpilaste identiteedi arenguga seotud tegureid, sh õpetajakoolituse tunnuste (nt praktika korralduse tüübi) ja üliõpilaste professionaalse identiteedi kujunemise seoseid. Seetõttu on suurenenud ka akadeemiline huvi õpetajate professionaalse identiteedi vastu (Akkerman \& Meijer, 2011).

Õpetajate professionaalse identiteedi uurimine kujunes iseseisvaks uurimisvaldkonnaks 1990ndatel, valdkonna kujunemisest ja algusaastatel läbiviidud uuringutest annavad põhjaliku ülevaate Beijaard jt (2004). Tänapäeval võib õpetajate professionaalse identiteedi uurimisel välja tuua kolm põhilist 
uurimissuunda. Esimene suund keskendub eelkõige erialaga seotud professionaalsuse kujunemisele. Sellistes uuringutes vaadeldakse õpetajale vajalike hoiakute, teadmiste ja oskuste kujunemist. Nii saab omavahel võrrelda algajate ja kogenud õpetajate pedagoogilise tööga seotud pädevusi (nt Berliner, 2001). Nende võrdluste põhjal selgitatakse, milliste küsimustega on vaja õpetajakoolituse õppekavades rohkem tegeleda, et erinevus algajate ja kogenute vahel väheneks (vt nt Krull, Oras, \& Sisask, 2007).

Olgugi et õpetajad jagavad sarnast sotsiaalset identiteeti, ei eksisteeri siiski ühetaolist õpetamiskultuuri ja iga õpetaja kujundab teatud määral unikaalse õpetamisviisi (Feiman-Nemser \& Floden, 1986). Teine professionaalse identiteedi uurimise suund keskendubki õpetaja personaalsusele. Tähtsal kohal on siin isiklikud tõekspidamised ja kogemused, mis mõjutavad professionaalse identiteedi kujunemist. Õpetajate enesemääratluse ja -reflektsiooni soodustamine võimaldab õpetajatel sõnastada enda jaoks olulised erialase tööga seotud küsimused ja otsida neile vastuseid (nt Cooper \& Olson, 1996). Sellise käsitlusviisiga seostub ka tänapäeval õpetajauuringutes suurt populaarsust kogunud õpetaja personaalse praktilise teadmise uurimine (ülevaate saamiseks vt nt Meijer, 2010).

Hilisemad autorid (nt Beijaard et al., 2004; Boreham \& Gray, 2005; Pillen, Den Brok, \& Beijaard, 2013), keda saab seostada õpetaja professionaalse identiteedi uurimise kolmanda uurimissuunaga, pööravad tähelepanu professionaalse identiteedi kahe variatsiooni seostatusele ja vastastikmõjudele. Mitmed hiljutised, viimase uurimistraditsiooniga seonduvad uurimused (vt nt Akkerman \& Meijer, 2011; Leijen \& Kullasepp, 2013a, 2013b; Ligorio, 2011) on õpetaja professionaalse identiteedi kujunemise, sh erinevate variatsioonide seoste ja vastastikmõjude paremaks mõistmiseks kasutanud dialoogilise käsitluse kontseptuaalset raamistikku (vt järgmine alapeatükk). Dialoogilised käsitlused võimaldavad arvestada õpetamise komplekssust (nt Darling-Hammond \& Snyder, 2000), personaalse praktilise teadmise rolli õpetamisel (nt Beijaard, Verloop, \& Vermunt, 2000) ja õpetamise laiemat taustsüsteemi (nt Clandinin, Downey, \& Huber, 2009). Käesolevas artiklis tutvustatakse õpetajakoolituse üliõpilaste professionaalse identiteedi kirjeldamiseks loodud testi, mis rajaneb viimasena kirjeldatud oppetaja professionaalse identiteedi uurimise traditsioonil.

Testi loomise eesmärk oli mõista õpetajate professionaalse identiteedi kujunemist. Uurimuses lähtutakse kultuuriliste-semiootiliste vahendite (nt keele) kasutamisest, kuivõrd inimese psühholoogiline toimimine kujuneb dialoogilistes vahetussuhetes keskkonnaga. Selle tulemusel konstrueeritakse tähenduste kujunemist reguleerivad süsteemid, mis omakorda kujundavad indiviidi enesemääratlust (Valsiner, 2007). Loodud test aitab üliõpilaste 
hulgas välja selgitada erialale vastava professionaalse rolli internaliseerimist subjektiivse tähendussüsteemi dünaamika kaudu.

Järgnevalt tutvustatakse uurimuse teoreetilisi lähtekohti, milleks on sotsiokultuurilise teooria semantilise vahendamise käsitus (Valsiner \& Rosa, 2007) ning dialoogilise mina teooria (Hermans \& Hermans-Konopka, 2010). Esimest neist on kasutatud sellise protsessi selgitamise raamistikuna, mis viib sotsiaalsete sõnumite integreerimiseni isiku identiteeti kujundaval viisil. Dialoogilise mina teooriast lähtudes on käsitletud spetsiifilisemalt uue rolli omaksvõtmisega seotud enesemääratluse ümberkujunemist.

\section{Enesemääratluse semantiliselt vahendatud kujunemine}

Sotsiokultuurilise käsitluse raames kirjeldatakse inimese psühholoogilise toimimise kujunemist vastastikmõjus keskkonnaga semiootiliselt vahendatud interaktsioonide kaudu. Dialoogilised suhted keskkonnaga tingivad olemasolevate tähenduste kohandamise ja uute tähenduste loomise (Valsiner \& Rosa, 2007). Seesugune isiku psüühilise maailma pidev rekonstrueerimine põhineb tajutava ja semiootilise materjali vahetusel keskkonnnaga (Valsiner, 2001).

Isiku ja keskkonna vaheline dialoog väljendub kihilises mudelis (laminal model) internaliseerimis- ja eksternaliseerimisprotsessina (Valsiner, 2001). Internaliseerimisprotsessis analüüsitakse ja sünteesitakse väliselt esinevat semiootilist materjali, andes sellele uue, psüühikas esineva vormi. Eksternaliseerimine on analüüsi- ja sünteesiprotsess, mille käigus toimub personaalse subjektiivse kultuuri ülekanne isikust väljapoole ning välise keskkonna modifitseerimine. Nende kahe protsessi puhul saab välja tuua kolm kihti, mille koostoime kaudu selgitatakse välise sõnumi integreerimist psüühiliste nähtuste struktuuri. Kihilise mudeli järgi integreeritakse sotsiaalne sõnum minaga (self), kui sõnum liigub läbi kihtide, millest igaühel on oma spetsiifiline funktsioon: 1) sõnumi märkamine ja (mina-)süsteemis säilitamine, 2) sõnumi üldistamine, 3) sõnumi integratsioon personaalse tähendussüsteemiga (personal sense system). Kõik sõnumid ei sisene esimesse kihti ning ka sinna sisenemisele ei pruugi järgneda sõnumi edasine töötlemine järgmistes kihtides.

Esimeses kihis on sõnumid isiku jaoks märgatavad, neid võidakse seal hoida, kuid nad võivad ka nõrgeneda ja kaduda. Selles kihis ei esine sõnum veel integreerituna isiku subjektiivse tunnetuse struktuuri. Järgmises kihis sõnum üldistatakse. Näiteks kui esimeses kihis olev sõnum on kuuldud/ loetud teadmine, et õpetaja X käitus viisil Y, siis teises kihis teeb üliõpilane üldistuse õpetaja rolli kohta, nt õpetaja roll eeldab käitumist viisil Y. Kui abstraktsele üldistusele ei lisandu subjektiivset nüanssi, ei ole sõnum veel integreeritud intrasubjektiivse süsteemiga. Näiteks võib pidada ratsionaalseid 
diskussioone abstraktsete probleemide üle, ilma et need sisaldaks afektiivset komponenti.

Alles kolmandas kihis on sõnum integreeritud viisil, mis kujundab isiku enesemääratlust ja selle väljendamist käitumisstrateegiates. Näiteks kui professionaalse rolliga seotud ootusi sisaldav sotsiaalne sõnum on internaliseeritud, hakkab see toimima märgina, mis juhib identiteedi kujunemist. Sellise semiootilise vahendi rakendamisel rolli sisenedes võetakse kasutusele erinevad käitumuslikud strateegiad, mis on kooskõlas rolliootustega. See viib teatud käitumisviisini professionaalsete suhete kontekstis (nt käitub õpetaja õpilastega suheldes viisil X, mis peegeldab tema arusaama õigest professionaalsest käitumisest) ning võib määrata enesearendamise suuna (nt kui arvatakse, et õpetaja peab olema hea suhtleja, püütakse parandada oma suhtlemisoskust). Lisaks võib internaliseeritud sõnum „ma saan tulevikus õpetajaks" viia muutuseni mina-tunnetuses, mis avaldub enesemääratluses „ma olengi juba õpetaja (kuigi ma alles õpin)”. Sel juhul on isik loonud (uue) tähenduse iseenda kohta („ma olen õpetaja”), peegeldades seega tähendusi loova regulatsioonisüsteemi osa oma identiteedi kujunemisel.

Professionaalse identiteedi kujunemise seisukohalt on oluline uurida üliõpilaste professionaalsesse rolli sisenemise individuaalset dünaamikat. Identiteedi kujunemine on peale sotsiaalsete-institutsionaalsete representatsioonide tasandi juhitud ka intrapsüühilisest tasandist. Sellele keskendutakse järgmises alapeatükis.

\section{Dialoogiline mina}

Intrapsüühilise dünaamika käsitlemiseks professionaalse rolli omaksvõtmisel on käesolevas uurimuses rakendatud dialoogilise mina teooriat (DMT) (Hermans, 2001; Hermans \& Hermans-Konopka, 2010). DMTs kirjeldatakse mina (self) kui süsteemi, mis koosneb suhteliselt autonoomsetest „häl̈lega” (voice) mina-positsioonidest, mille vahel mina pidevalt kõigub. Erinevad mina-positsioonid kujunevad mitmesuguste ajalooliste, kultuuriliste, institutsionaalsete ja sotsiaalsete kogemuste kaudu. Seega võib üliõpilaste liikumist uue tegevusala sotsiokultuurilisse keskkonda vaadelda kogemusena, mis toetab uue positsiooni tekkimist (nt „mina kui professionaal”). Kuna DMT võimaldab vaadelda professionaalse rolli omaksvõttu, arvestades teisi üliõpilaste enesemääratluse tahke (nt „mina kui isik”) ja nendevahelist dünaamikat, on see teooria käesoleva uurimisküsimuse seisukohalt sobiv.

Siinses uurimuses käsitletakse professionaalset mina-positsiooni kui positsiooni, mis kujuneb isiku ja sotsiokultuurilise keskkonna dialoogi kaudu ning mille loomine on ajas kestev mitmetasandiline protsess. Mina- 
positsiooni „mina kui õpetaja” kujunemist vormivad professionaalset rolli määratlevad institutsionaalsed-professionaalsed regulatsioonid, mis raamivad professionaalseid praktikaid ning on seotud erialaste tegevuste, piirangute, kohustuste ja muuga. Samas pole formaalsed rolliootused ainukesed positsiooni arengu allikad, vaid positsiooni kujunemist mõjutavad ka erialase tegevuse ja õpingutevälised tegurid. Näiteks leidis Kullasepp (2008) psühholoogiaüliõpilaste professionaalset identiteeti käsitlevas uurimuses, et pereliikmete, sõprade ja tuttavate rolliootused mõjutavad üliõpilaste suhestumist professionaalse rolliga.

Mina-positsioonide paljusus mina-süsteemis tähendab ühtlasi hulka samaaegseid autonoomseid „hääli”, mis põhjustavad mitmehäälsust. Mitmehäälsus väljendub perspektiivide paljususes ja tingib erinevate tähenduste loomist võimaldavad allsüsteemid. Teatud olukorrale võidakse anda erinevaid tähendusi olenevalt sellest, millised mina-positsioonid on dialoogi kaasatud (nt „mina kui professionaal pean tegema X-i, kuid mina kui isik ei tahaks seda teha"). Selline mina-süsteemi käsitus annab võimaluse võtta vaatluse alla professionaalse identiteedi kujunemise ning jälgida minapositsiooni ilmnemist institutsionaalse või professionaalse tegevuse kontekstis ja selle suhteid teis(t)e mina-positsiooni(de)ga.

Erinevate mina-positsioonide („mina kui õpetaja” <> „mina kui isik”) suhete ja sobivuse (kooskõla/ebakõla) uurimine on oluline, sest mina-positsioonide ebakõlade kõrvaldamine võib aidata tulevastel õpetajatel kohaneda ootustega professionaalse rolli suhtes.

\section{Ambivalentsus}

Uurimuses on lähtutud seisukohast, et mina-positsioonide („mina kui isik” ja „mina kui professionaal”, nt „mina kui õpetaja”) erinevus loob eeldused ambivalentsuse tekkeks professionaalse rolli internaliseerimisel minasüsteemi. Selles uurimuses tähistab termin „ambivalentsus” tingimusi, mille korral ilmnevad süsteemis tähenduste loomisega seotud erisuunalised protsessid (Abbey \& Valsiner, 2005). Tegemist on erinevaid perspektiive ja tähendusi loovate mina-terviku allsüsteemidega, mis võivad väljenduda dilemmade kogemises, sisekonfliktides, süsteemisiseses dissonantsis vms. Üks isik võib end määratleda semiootilisi vahendeid kasutades mitmeti (nt „mina kui õpetaja”, „mina kui laps”, „mina kui kolleeg”).

Ambivalentsus (võimalus määratleda end mitmeti) on oluline tegur professionaalse rolli internaliseerimise protsessis (Kullasepp, 2008). Teoreetiliselt võib eeldada, et ambivalentsus, mis tekib kahe erineva positsiooni olemasolul, kutsub esile süsteemisisese pinge ning püüdluse see kõrvaldada. Pinge 
kõrvaldamisel rakendatakse semiootilisi vahendeid, mis peegeldavad subjektiivseid tundeelamuslikke reageeringuid (STR) ja nende suunda. STRid võivad olla negatiivse suunaga (nt viha), positiivse suunaga (nt rõõm) või neutraalsed.

Olukorraga, kus dialoogis on kaks erinevat mina-positsiooni ja üks positsioon domineerib teise üle, võib kohaneda (või mitte kohaneda). Nii võib see toimuda juhul, kui probleemile lähenetakse professionaalselt (nt rakendades rollikäitumist reguleerivaid formaalseid reegleid). See võib osutada professionaalse rolli ilmnemisele mina-süsteemis, kuid mitte veel selle sobitumisele teiste mina-positsioonidega.

Käesolevas uurimuses vaadeldakse, kuidas õpetajakoolituse üliõpilased koordineerivad personaalset ja professionaalset mina-positsiooni erialaste ambivalentsete olukordade kontekstis. Kooskõlas DMTga oletatakse, et rolliootuste internaliseerimine ja integreerimine mina-süsteemiga väljendub mina-positsioonide sobivuses ning negatiivse pinge, sh STRi väiksemas esinemissageduses. Seda oletust toetavad ka huvijuhtide õppekava üliõpilaste hulgas läbi viidud uuringu tulemused (Leijen \& Kullasepp, 2013a), mis näitasid, et kahel mõõtmisel stabiilselt professionaalselt positsioonilt vastanud üliõpilaste vastustes osutati vähem negatiivsetele emotsioonidele. Lisaks eeldatakse uurimuses, et rolli internaliseerimine professionaalsete praktikate (sh ülikooliõpingute) käigus toob kaasa professionaalse mina-positsiooni sagedasema domineerimise ja on märk omandatud erialastest teadmistest, oskustest ja valmisolekust rakendada erialakontekstis professionaalset minapositsiooni. Ka varasemad uurimused on viidanud erialase ettevalmistuse perioodile kui ajale, mil toimuvad muutused identiteedis ning valmisolekus käituda professionaalse rolli ootuste kohaselt. Näiteks leidsid Bruss ja Kopala (1993), et õpingud tähendavad sattumist uusi võimalusi pakkuvasse keskkonda ning see viib mina-siseste muutusteni. Samuti on kirjeldatud tulevaste psühhoterapeutide hoiakute muutumist ja vajadust käituda moraalselt (van Zandt, 1990).

\section{Uurimuse eesmärgid ja uurimisküsimused}

Uurimusel on kaks eesmärki. Üks eesmärk on luua test, mille abil saab uurida õpetaja professionaalse identiteedi kujunemist, lähtudes kihilisest mudelist (Valsiner, 2001) ja DMTst (Hermans, 2001; Hermans \& Hermans-Konopka, 2010), ning mis võimaldaks seega jälgida professionaalse mina-positsiooni internaliseerimist. Teine eesmärk on otsida lisatõendeid õpetaja professionaalse rolli internaliseerimisega seotud tegurite kohta. Täpsemalt otsitakse vastuseid järgmistele uurimisküsimustele. 
1. Kuidas seostuvad professionaalse mina-positsiooni väljendamine ja antud olukorras professionaalile omistatav subjektiivne tundeelamuslik reageering (STR)? Selle küsimuse esitamine lähtub DMTst, mis seostab pingesituatsioonide kogemise erialases kontekstis ebakõlaga mina-positsioonide vahel, mis osutab, et uus positsioon ei ole veel sobitunud olemasolevatega. Seega sõnastati esimene hüpotees järgmiselt: professionaalse rolli enam omaks võtnud üliõpilased, kes ühtlasi on suutnud paremini erinevatest „häältest” tulenevat ambivalentsust ületada, osutavad erialaste olukordade kontekstis harvem negatiivsetele STRidele.

2. Kuidas seostub töö- ja öppimiskogemus professionaalse mina-positsiooni väljendamisega? Selle küsimuse puhul eeldati, et professionaalse minapositsiooni kujunemine on seotud osalemisega institutsionaalsetes/professionaalsetes tegevustes, ning uuringu teine hüpotees sõnastati järgmiselt: üliõpilased, kellel on enam töö- ja õppimiskogemusi, väljendavad sagedamini professionaalset mina-positsiooni.

\section{Metoodika}

\section{Valim}

Andmed koguti ühe ülikooli aineõpetaja magistriõppe (õpetajakoolituse esmaõppe) üliõpilastelt. Aineõpetaja õpingud kätkevad selles ülikoolis tüüpiliselt kolme aastat erialaõpinguid bakalaureuseõppes ning kaks aastat vältavat õpetajakoolitust magistriõppes. Magistriõppe esimesel aastal võetakse osa nii ainevaldkonna kui ka pedagoogikaga seotud ainekursustest, teisel aastal osaletakse peale ainekursuste ka koolipraktikas (10 nädalat), mis toimub vastavalt õppekavale kas novembrist jaanuarini või jaanuarist märtsini. Katsealustena kasutati aineõpetaja magistriõppe üliõpilasi, kes olid oma õpingutes erineval kaugusel: õpingute päris alguses, esimese õppeaasta lõpul ning teise õppeaasta keskel enne koolipraktikat. Kokku osales uuringus 109 isikut, sh 70 äsja õpinguid alustanud üliõpilast (67\%), 16 esimese aasta läbinut ja 18 teise aasta keskele jõudnud üliõpilast (kokku 32\% õppes osalemise kogemusega vastajat). Vastajate hulgas oli nii neid, kellel õpetajana töötamise kogemus täielikult puudus (54\%), kui ka neid, kellel juba oli õpetajana töötamise kogemus. 76\% vastanutest oli naissoost. Valimi sooline jaotus vastab üliõpilaste soolisele jaotusele uuringusse kaasatud õppekavade arvestuses (naissoost üliõpilaste osakaal jäi andmekogumise ajal vahemikku 70$80 \%$ ). Uuringus osalemine oli vabatahtlik, osalejate vahel loositi välja kolm raamatupoe kinkekaarti (igaüks väärtusega 30 eurot). 


\section{Mõõtevahend}

Õpetaja professionaalse rolli omaksvõtu dünaamika hindamiseks kasutatakse testi, mille aluseks on psühholoogiaülioopilaste professionaalse identiteedi kujunemise uurimiseks loodud DDTC (Double Direction Theme Completion) mõõtevahend (Kullasepp, 2008). See põhineb traditsioonilisel lausete lõpetamise meetodil (Symonds, 1947). Tegemist on projektiivtehnikaga, mis suunab vastajat nimetama tunnet, mida ülesandes kirjeldatud olukord tekitab, ning seejärel lisama põhjenduse, miks selline tunne tekib. DDTC võimaldab luua personaalse orientatsiooni ja professionaalsesse rolli sisenemise koordineerimise profiili, mis vastavalt ootustele muutub aja jooksul. Need muutused väljenduvad selles, kuidas vastaja konstrueerib iseenda suhestumist rolliga vastamise hetkel. DDTC loomisel lähtuti seisukohast, et iga professionaal (nt psühholoog või õpetaja) on ennekõike isik, kes internaliseerib professionaalse rolli. See toimub subjektiivselt tajutud sotsiaalse representatsiooni (nt õpetaja, psühholoogi) omaduste internaliseerimise ja personaalse kultuuriga integreerimise kaudu. DDTCs lahendamiseks pakutud dilemmad kirjeldavad ambivalentset olukorda (ISIK $<>$ ROLL, st isik $\neq$ psühholoog/õpetaja, vaid need on erinevad mina-allsüsteemid) ning nende lahendused võimaldavad välja selgitada semiootilised regulaatorid, mida vastajad on rakendanud ambivalentse olukorraga toimetulemiseks. Katsealuse vastused sisaldavad 1) ülesandes kirjeldatud situatsiooni tõlgendust, sh subjektiivseid tundeelamuslikke reageeringuid, 2) dilemma lahendamise võimalusi (nt „mina kui isik”, „mina kui professionaal”) (Kullasepp, 2008; Leijen \& Kullasepp, 2013a).

DDTC-Õpetaja, mis loodi siinse uurimuse raames õpetaja professionaalse rolli omaksvõtmise dünaamika selgitamiseks, sisaldab üheksat professionaalse rolliga seotud dilemmat (vt lisa 1). Dilemmade valikul lähtuti erinevatest ambivalentsetest situatsioonidest, mis hõlmavad 1) õpilase iseärasusi, 2) aine õpetamist, 3) kolleegide ja lapsevanemate ning tuttavatega suhtlemist. Valiti situatsioonid, mis aktiveeriksid seesmise dialoogi minapositsioonide „mina kui isik” ja „mina kui professionaal” vahel (ISIK <> ROLL). Dilemmade sobivusele andsid hinnangu kaks pikemaajalise töökogemusega praktiseerivat õpetajat ja üks õpetajakoolituse õppejõud.

\section{Andmete kodeerimine}

Andmete kodeerimine koosnes kahest etapist. Esiteks määrati vastustes, kas kahe mina-positsiooni vahel esineb pinge või mitte. Pinget määrati vastustes esitatud negatiivse STRi kaudu. Näiteks kui üliõpilane kirjutas esimesse ülesande lünka (vt lisa 1) kogetava tunde kohta halvasti, rusutuna, reeturina, süümepiinu jms, kodeeriti vastus kui negatiivne STR ja tähistati väärtusega 1. 
Juhtudel, kus üliõpilased kirjeldasid neutraalseid subjektiivseid reaktsioone (nt vastutavana, kohustatuna) või positiivseid reaktsioone (nt hästi, heameelt, rõomu), kodeeriti vastused negatiivse STRi mitteesinemisena ja tähistati väärtusega 0 .

Seejärel määrati ülesande teises lüngas esitatud vastuse mina-positsioon. Mina-positsiooni kodeerimisel eristati professionaalse rolli esinemist. Varem kirjeldatud reeglite järgi (vt Kullasepp, 2008; Leijen \& Kullasepp, 2013a) kodeeriti vastus professionaalsele rollile viitamisena järgmistel juhtudel: 1) vastuses kirjeldati tööülesandeid, pädevusi või tööprotsessi (nt tema ülesandeks on oppilastele oma aine selgeks teha ja hoolitseda selle eest, et nad valdaks ainet) või 2) vastuses osutati professionaalsetele tegevuse regulatsioonidele ja reeglitele moraalsete imperatiivide (ei tohi, peab) vahendusel (nt õpilasel jääb oluline info arusaamatuks ning õpetaja peab oma metoodikas midagi muutma). Vastused, kus viidati professionaalsele mina-positsioonile, kodeeriti väärtusega 1, ülejäänud said väärtuse 0 . Vastuseid kodeeris üks uurija. Kodeerimise reliaabluse hindamiseks valiti andmebaasist juhuslikult 81 vastust ( 9 tudengi vastused 9 dilemmale), mida analüüsis teine uurija, et selgitada välja kodeerijatevaheline kooskõla. Siinses uurimuses oli see STRi määramisel 0,96 (Coheni kappa) ja professionaalse mina-positsiooni määramisel 0,91 (Coheni kappa).

Mõõtevahendi sisereliaabluse hindamine osutas, et neljanda dilemma (... sõber palub ópetajat, et ta võtaks tema lapse huviringi, kus on kohad juba täis ...) ja kaheksanda dilemma (... peab suhtlema lapsevanemaga, kes on väga ebameeldiv ...) kohta loodud muutujate seos mõõtevahendi skooriga oli väga nõrk ning need dilemmad eemaldati. Nende dilemmade püstitus erines sisult teistest, mis keskenduvad vahetult õpetamisest ja õpilase omadustest lähtuvatele olukordadele. Analüüsis kasutatud vastajate skooride leidmiseks liideti alles jäetud seitsme muutuja väärtused $(M=3,66, S D=1,74$, $\min =0$, max $=$ $7, N=97)$. Mõõtevahendi sisereliaablus jäi kaheldavale tasemele (Cronbach $\alpha=0,65)$, kuid arvestades andmete kodeerimise viisi, peeti seda küllaldaseks, et neid skoore analüüsis kasutada.

\section{Andmeanalüüs}

Muutujatevaheliste seoste uurimiseks on läbivalt kasutatud sagedusanalüüse. Kahe muutuja vahelist seost on hinnatud hii-ruut testiga. Komplekssemate seoste esiletoomiseks on kasutatud konfiguratsioonilist sagedusanalüüsi (KSA), mis võimaldab andmeid täiendavalt üldistamata hinnata, kas teatud tunnuste kombinatsiooniga juhtusid esineb valimis sagedamini (esineb tüüp) või harvemini (esineb antitüüp), kui võiks esineda juhuslikult (von Eye, 
1990). Kui mitmete levinud analüüsimeetodite (nt regressiooni, dispersioonanalüüsi) tulemused väljendavad muutujatevahelist üldistatud seost, mis tingimata ei vasta hulga uuritud indiviidide puhul teatud tunnuste esinemisele samasuguses või ka samasuunalises seoses, võimaldab KSA välja tuua valimi alarühmad, mille kõiki liikmeid iseloomustab ühesugune koos esinevate tunnuste muster. Seetõttu on seda meetodit laialdasemalt kasutanud indiviidile orienteeritud lähenemise (person-oriented approach) esindajad, kes käsitlevad indiviidi kui ainulaadset organiseeritud tervikut ja keskenduvad indiviidi käitumise mõistmiseks talle omaste tunnuste ja nendevaheliste seoste analüüsimisele tervikuna (Bergman \& Magnusson, 1997). KSA läbiviimiseks kasutati programmi EXACON, mis on osa statistilise andmetöötluse paketist Sleipner (Bergman \& El-Khouri, 2002).

\section{Tulemused}

Testi sisereliaabluse analüüsimine (vt ülal) osutas, et käesoleva uuringu puhul võib arvata, et vastused kajastasid pigem vastajate sama omadust (tegemist on pigem samadimensioonilise mõõtevahendiga) ning saadud tulemused ühtlasi ka eristasid vastajaid. Samas leiti sisereliaabluse analüüsimisel viiteid sellele, et professionaalse mina-positsiooni (PMP) eelistamine võib olenevalt kirjeldatud olukorrast varieeruda - eristusid ülesanded (nt kolleegi või lapsevanemaga seotud dilemmad), mille puhul vastajate mina-positsiooni eelistused ei langenud kokku nende eelistustega teiste ülesannete puhul. Seega osutavad praegu analüüsidest kõrvale jäetud ülesanded, et PMP kujunemist tuleks veel uurida, võttes arvesse erinevusi olukordades või tegevustes, mida õpetajad käsitavad oma erialase tegevusena.

\section{Vastavus mina-positsiooni väljendamise ja subjektiivse tundeelamusliku reageeringu omistamise vahel}

Esimesele uurimisküsimusele vastamiseks - ning seega mina-positsiooni liikide (PMP ja mitte-PMP) ja STRi omistamise vastavuse selgitamiseks loodi neli indeksit. Esimese indeksi väärtused näitavad, mitmel korral osutas vastaja PMPd väljendades ühtlasi mittenegatiivsele STRile (neutraalne või positiivne) $(M=1,55, M D=1, \min =0, \max =5)$. Teise indeksi väärtused osutavad, mitu korda oli vastaja PMPd väljendades viidanud negatiivsele STRile $(M=2,06, M D=2$, $\min =0, \max =5)$. Kolmas ja neljas indeks puudutavad neid ülesannete vastuseid, kus vastaja ei väljendanud PMPd. Kolmanda indeksi väärtused näitavad, mitu korda vastaja väljendas mitte-PMPd koos mittenegatiivse STRiga $(M=0,97, M D=1, \min =0, \max =4)$. Neljanda 
indeksi väärtused näitavad, mitmes ülesandes vastaja väljendas mitte-PMPd, osutades ühtlasi negatiivsele STRile $(M=2,44, M D=2$, $\min =0, \max =7)$. Analüüside tegemiseks kodeeriti kõigi indeksite väärtused ümber, määrates iga juhu puhul kindlaks, kas tegemist on indeksi kõrgema tasemega (suurem kui indeksi mediaanväärtus) või madalama tasemega (väiksem kui indeksi mediaan või sellega võrdne). Seejärel koondati neli indeksit üheks muutujaks, milles esines kümme kategooriat, mis väljendasid indeksite madalamate ja kõrgemate tasemete koosesinemist. Võimalikke indeksite tasemete kombinatsioone on 16, kuid neist mõne esinemine on väga ebatõenäoline või võimatu (nt kombinatsioon, kus kõrge tase esineks korraga nii neil indeksitel, mis osutavad PMP sagedasele väljendamisele, kui ka neil, mis väljendavad sagedast muud tüüpi mina-positsiooni).

Seejärel viidi läbi konfiguratsiooniline sagedusanalüüs, kuhu kaasati ühe muutujana indeksite väärtuste kombinatsioone väljendav muutuja. Analüüsi sisestati ka PMP üldskoor, mis oli selle analüüsi jaoks ümber kodeeritud, eristades väärtusega 1 kõrgema tulemusega vastajaid (skoor on suurem kui kolm) ja väärtusega 0 madalama tulemusega vastajaid (skoor on kolm või väiksem). Analüüsi tulemused on toodud tabelis 1. Tulemused näitavad, et ootuspäraselt esineb oluliselt sagedamini kui juhuslikult muutujate kombinatsioone (vt tabel 1, mustrid 1 ja 2), kus koos on väiksem PMP skoor ja madalam PMP kasutamise tase nii negatiivsete kui ka mittenegatiivsete STRide kontekstis. Samas on mitte-PMP kasutamisega seotud indeksite tase kas negatiivsetele STRidele või nii negatiivsetele kui ka mittenegatiivsetele STRidele osutamise kontekstis kõrge. Seega võib mitte-PMP sagedasem kasutamine näidata ühteaegu negatiivsele ja mittenegatiivsele STRile osutamist.

Samuti ootuspäraselt esineb tüübina suurem PMP skoor koos PMP kasutamise põhjal loodud indeksite kõrgema tasemega (vt tabel 1, mustrid 3 ja 4). Neis mustrites on mitte-PMP väljendamisega seotud indeksitel seega madalam tase. Võrreldes nende tüüpidega, mis iseloomustasid väikse PMP skooriga vastajaid, võib STRide omistamises täheldada mõningast erinevust. Eraldi tüübina esineb samuti kombinatsioon, kus vastajad on õpetajale sagedamini omistanud negatiivse tundeelamuse.

Seega on mina-positsiooni iseloomust olenemata vastajad mõistnud kirjeldatud olukordi õpetajas pigem pinget ja ebameeldivaid elamusi tekitavana. Võib täheldada, et suurema PMP skoori korral kerkis tüübina esile ka muster (muster 3), millele on iseloomulik mittenegatiivsele STRile osutamine. Väiksema PMP skoori puhul väljendati küll samuti mittenegatiivseid tundeid, kuid tüüpiline oli ka negatiivsele STRile osutamine. Seega näitavad tulemused, et mittenegatiivsele STRile osutamine on iseloomulik just suurema professionaalse mina-positsiooni skooriga üliõpilaste hulgas. 


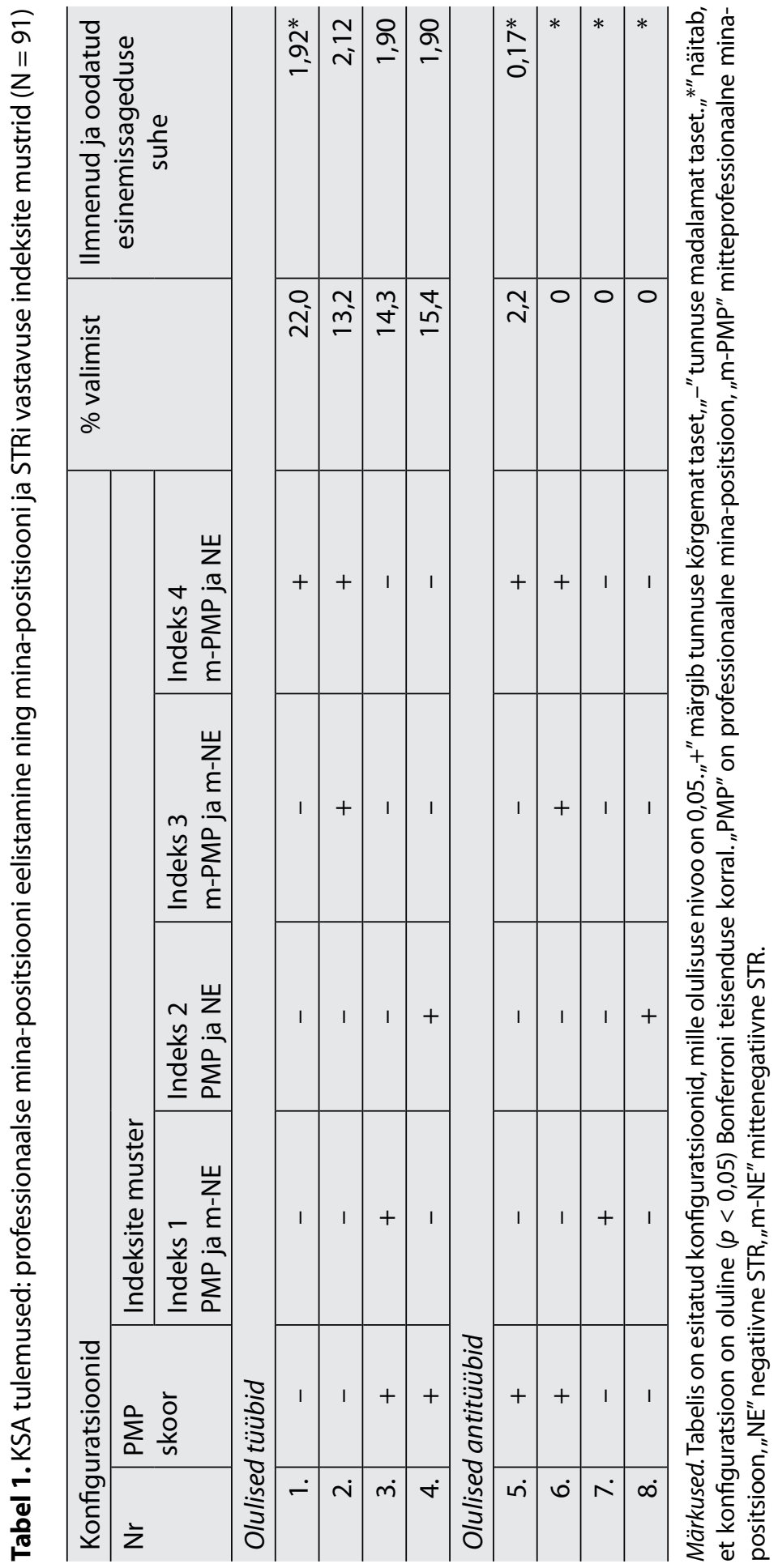


Ilmnenud antitüübid on kooskõlas esinenud tüüpidega, kui võtta arvesse, et teatud PMP skoori taseme puhul ilmnenud tüübid esinevad teise PMP skoori taseme puhul antitüüpidena.

\section{Mina-positsioon ning töö- ja õppimiskogemus}

Teooriale tuginedes oletati, et mina-positsioonide internaliseerimise kulg on seotud teatud rollis tegutsemise kogemustega (Hermans \& HermansKonopka, 2010). Seega sõnastati teisest uurimisküsimusest tulenev hüpotees järgmiselt: suurem erialase töö ja õppimise kogemus on seotud professionaalse mina-positsiooni sagedasema kasutamisega. Hüpoteesi kontrollimiseks moodustati kaks muutujat. Esiteks loodi töökogemuse muutuja, mis eristab üle aasta õpetajana töötanud üliõpilasi (väärtus 2) kuni aasta töötanud üliõpilastest (väärtus 1). Teiseks loodi õpetajakoolituse kogemuse muutuja, mille väärtused eristavad uustulnukaid (kodeeriti väärtusega 1) aasta või kauem õppinud üliõpilastest (väärtus 2).

Hii-ruut testi põhjal selgus, et erinevalt väiksema või puuduva töökogemusega isikutest kasutasid suurema töökogemusega isikud sagedamini PMPd. Samas õppimiskogemusest lähtudes PMP skooride tasemed oluliselt ei erinenud: äsja õpinguid alustanud üliõpilaste tulemused ei eristunud aasta või kauem õppinute omadest.

Kui kirjeldada PMP skooride jaotust korraga töö- ja õppimiskogemuse foonil, selgub, et töökogemuseta uustulnukate hulgas on levinumad keskmised skoorid, ent esindatud on ka väiksemad ja suuremad skoorid $(M D=4$, $\min =1, \max =7, N=54$ ). Töökogemuseta, kuid vähemalt aasta õppinud üliõpilasi iseloomustavad üldiselt kõige madalamad tulemused $(M D=3, \min =0$, $\max =5, N=17)$. Töökogemusega üliõpilastel on üldiselt suuremad skoorid (sh uustulnukad: $M D=4, \min =2, \max =5, N=12$; oppinud vähemalt aasta: $M D=5, \min =4, \max =7, N=7)$. Selline jaotus näib viitavat sellele, et professionaalse mina-positsiooni kriteeriumitele vastavaid vastuseid võivad anda ka need isikud, kellel puudub nii töö kui ka õpetajakoolituse kaudu saadud õpetajatöö kogemus. Ilmselt on neil - nagu valdaval osal ühiskonna liikmeist mitmekesised koolikogemused ning õpetajatöö normide vm ootustega seotud teadmised ja eelistused, millest nad vastamisel lähtusid. Kuigi selliste erialase kogemuseta isikute vastustes võib esineda ka suuri PMP skoore, tasub tähele panna, et üldiselt on need skoorid väiksemad kui töökogemusega isikutel.

Kuigi töökogemusega uustulnukad kalduvad natuke enam õpetajaameti positsioonilt vastuseid andma, on kõige kõrgemad tulemused valimis väikesel grupil töökogemusega ja ühtlasi õpetajakoolituse kogemusega üliõpilastel. Sellise töö- ja õppimiskogemusega tudengite PMP skoorid on teiste rühmade liikmetega võrreldes oluliselt sagedamini suuremad, $\chi^{2}(1,89)=4,28, p<0,05$. 
Eeltoodu taustal võiks olla huvitav tähelepanek, et kõige väiksemad PMP skoorid iseloomustasid õpetajakoolituses osalejaid, kellel puudus töökogemus. See on samuti väike rühm, kuid siia kuuluvad sellistel õppekavadel õppivad üliõpilased, kellel oma õpingute kaudu puudub koolis töötamise kogemus.

Kokkuvõttes võib osutada, et teise uurimisküsimuse puhul leidis toetust oletus, et suurem töö- ja õppimiskogemus seostub professionaalse minapositsiooni sagedasema kasutamisega. Eraldi võetuna leiti oluline seos just töökogemuse ja PMP võtmise vahel. Lisaks täheldati, et kõige sagedamini iseloomustavad suuremad PMP skoorid neid üliõpilasi, kellel on nii töö- kui ka õppimiskogemus, madalamaid tulemusi said töökogemuseta, kuid juba vähemalt aasta õppinud üliõpilased. Peale selle ilmnes teoreetilises plaanis huvitav seik, et ka ilma töö- ja õppimiskogemuseta üliõpilased võivad saavutada suuri PMP skoore.

\section{Arutelu}

Käesolevas uurimuses koostati kihilisele mudelile (Valsiner, 2001) ja DMTle (Hermans, 2001; Hermans \& Hermans-Konopka, 2010) tuginedes mõõtevahend õpetaja professionaalse rolli internaliseerimise dünaamika hindamiseks. Mõõtevahendi sisereliaablus jäi mõnevõrra madalaks, kuid arvestades nii kasutatud andmete kodeerimise viisi kui ka väikest valimit, peeti seda praegusel juhul küllaldaseks. Mõõtevahendi omadustele täpsema hinnangu andmiseks on vaja koguda uurimisandmeid suuremalt hulgalt õpetajakoolituse üliõpilastelt. Peale selle võiks kaaluda mitmedimensioonilise PMP vahendi loomist (vt allpool).

Mõõtevahendiga kogutud andmete põhjal uuriti kõigepealt vastustes välja toodud professionaalse mina-positsiooni väljendamise ja ambivalentses olukorras professionaalile omistatava STRi vastavust. Kooskõlas ülesannete loomise kavatsustega näitasid uurimistulemused, et sõltumata mina-positsiooni iseloomust mõistsid vastajad kirjeldatud olukordi kui õpetajas pinget ja ebameeldivaid elamusi tekitavatena. Sellele lisaks osutasid saadud tulemused, et suurema PMP skooriga juhtudele on iseloomulik mittenegatiivsele STRile osutamine. Uurimuses oletasime, et professionaalse rolli internaliseerimine vähendab pingeid, mistõttu väheneb ka negatiivsete STRide omistamine professionaalile. Nimetatud hüpotees leidis seega kinnitust.

Lisaks uuriti seoseid töö- ja õppimiskogemuse ning professionaalse mina-positsiooni esinemise vahel. Kinnitust leidis hüpotees, et suurem töö- ja õppimiskogemus seostub professionaalse mina-positsiooni sagedasema kasutamisega. Oluline seos tuli välja just töökogemuse ja professionaalse minapositsiooni kasutamise vahel. Oppimiskogemus eraldiseisvana viimasega ei 
seostunud. Seega näitavad tulemused, et just õpetajana tegutsemise kogemused viivad enda sagedasema määratlemiseni õpetajana. Tulemused osutavad, et õpetajatöö praktikata üliõpilasi võiks klassifitseerida kui kogenud kõrvaltvaatajaid, kellele kõneletakse õpetajatööst, kuid see ei seostu nende reaalse tegevusega. Saadud tulemused võivad viidata sellele, et ülikooli- ja teooriakeskne õpetajakoolitus üksi ei toeta erialase rolli internaliseerimist, nagu on näidanud ka varasemad uuringud (vt nt Alsup, 2006; Danielewicz, 2001), kuid seda võiks soodustada töökogemuse ja õpingute integreerimine (vt ka Korthagen, 2001; Korthagen \& Vasalos, 2005). Ülikoolis, kus õpivad siin kirjeldatava uurimuse katsealused, on see õppekavade liik praegu muutmisel. Uuenduste järel suureneb õpetajakoolituses praktika osakaal: praktika on integreeritud teooriaõpingutega. Käesoleva uurimuse tulemused näitavadki, et sellised sammud on professionaalse enesemääratluse kujunemise toetamiseks vajalikud.

Ühtlasi osutavad saadud tulemused uurimuse tarbeks välja töötatud mõõtevahendi sisulisele valiidsusele: PMP kasutamine on sagedasem suurema töökogemusega üliõpilaste hulgas; PMP sagedasemate kasutajate puhul tuleb esile rühm, keda iseloomustas mittenegatiivsete STRide sagedasem omistamine. Samas ilmnes huvitava tulemusena, et suuri PMP skoore andsid ka töö- ja õppimiskogemuseta üliõpilased. On siiski võimalik, et nende üliõpilaste puhul leiab Valsineri (2001) kihilise mudeli järgi aset sotsiaalse sõnumi liikumine esimese (märkamise) ja teise (üldistamise) kihi vahel, seevastu sotsiaalse sõnumi integreerimine personaalse tähendussüsteemiga ei ole veel toimunud. Sellised vastajad võivad läbi viia abstraktseid emotsionaalselt mittesiduvaid arutelusid, mis veel ei seostu enesemääratlemise võimaluste ega valitavate tegevusviisidega. Edasise uurimistöö käigus soovivad autorid väljatöötatud küsimustikku täiendada, et sellega saaks internaliseerimise erinevaid kihte täpsemalt eristada.

Uurimuse üks peamisi piiranguid on valimi väiksus: artiklis tutvustatud uurimistulemuste täpsustamiseks tuleb edasistes uuringutes valimisse kaasata suurem hulk töö- ja õppimiskogemusega õpetajakoolituse üliõpilasi. Suurema valimi korral võiks lisaks uurida erinevusi ülesannete lahendamisel, sest praegusel juhul leidus ülesandeid, mille puhul vastajate minapositsiooni eelistused ei langenud kokku nende eelistustega teiste ülesannete puhul. Oodatult on õpetajatöö osaliselt indiviiditi erineva sisuga, samas on ka ootuspärane, et osa õpetajatöö põhimõtteid jagavad kõik õpetajad (vt Beijaard et al., 2004; Burke \& Stets, 2009).

Edasise uurimistöö käigus võiks keskenduda professionaalse ja personaalse identiteedi sügavamale analüüsile ja välja selgitada võimalikke arengulisi iseärasusi rolli internaliseerimisel algajate ja kogenud õpetajate hulgas. Lõpetuseks on oluline märkida, et käesolevas uurimuses keskenduti peamiselt 
professionaalse rolli internaliseerimise uurimisele, edaspidi võiks vaatluse alla võtta ka teised õpetaja mina-positsioonid, nt „mina kui lapsevanem”, „mina kui rahvusgrupi liige”. Huvitav oleks vaadelda nende positsioonide seoseid õpetaja professionaalse rolliga, sest professionaalse identiteedi eesmärk ei ole ainult enda identifitseerimine õpetajana, vaid ka kooskõla loomine oma elu teiste rollidega (Alsup, 2006).

\section{Tänusõnad}

Uurimuse valmimist toetas sihtasutus Eesti Teadusfond (grandiprojekt ETF9221) ja Euroopa Sotsiaalfond (grandiprojekt ÕPA, Eduko programm).

\section{Kasutatud kirjandus}

Abbey, E., \& Valsiner, J. (2005). Emergence of meaning through ambivalence. FQS, 6(1), 23. Retrived from http://www.qualitative-research.net/index.php/fqs/article/ view/515/1114.

Akkerman, S. F., \& Meijer, P. C. (2011). A dialogical approach to conceptualizing teacher identity. Teachers and Teacher Education, 27(2), 308-319.

http://dx.doi.org/10.1016/j.tate.2010.08.013

Alsup, J. (2006). Teacher identity discourses. Mahwah: Lawrence Erlbaum Associates.

Anspal, T., Eisenschmidt, E., \& Löfström, E. (2012). Finding myself as a teacher: Exploring the shaping of teacher identities through student teachers' narratives. Teachers and Teaching: Theory and Practice, 18(2), 197-216. http://dx.doi.org/10.1080/13540602.2012.632268

Beijaard, D. (1995). Teachers' prior experiences and actual perceptions of professional identity. Teachers and Teaching: Theory and Practice, 1(2), 281-294. http://dx.doi.org/10.1080/1354060950010209

Beijaard, D., Meijer, P. C., \& Verloop, N. (2004). Reconsidering research on teachers' professional identity. Teaching and Teacher Education, 20(2), 107-128. http://dx.doi.org/10.1016/j.tate.2003.07.001

Beijaard, D., Verloop, N., \& Vermunt, J. (2000). Teachers' perceptions of professional identity: An exploratory study from a personal knowledge perspective. Teaching and Teacher Education, 16(7), 749-764. http://dx.doi.org/10.1016/S0742-051X(00)00023-8

Bergman, L. R., \& El-Khouri, B. (2002). SLEIPNER - a statistical package for patternoriented analyses. Vs. 2.1, 2002. User Manual. Stockholm: Stockholm University.

Bergman, L. R., \& Magnusson, D. (1997). A person-oriented approach in research on developmental psychopathology. Development and Psychopathology, 9(2), 291-319. http://dx.doi.org/10.1017/S095457949700206X

Berliner, D. C. (2001). Learning about and learning from expert teachers. International Journal of Educational Research, 35(5), 463-482. http://dx.doi.org/10.1016/S0883-0355(02)00004-6 
Bohl, J. V., \& van Zoest, L. R. (2002). Learning through identity: A new unit of analysis for studying teacher development. In A. D. Cockburn \& E. Nardi (Eds.), Proceedings of PME 26 Conference Vol. 2 (pp. 137-144). Norwich: University of East Anglia.

Boreham, N., \& Gray, P. (2005) Professional identity of teachers in their early development. Early learning project. Research report. University of Sterling.

Bruss, K. V., \& Kopala, M. (1993). Graduate school training in psychology: Its impact upon the development of professional identity. Psychotherapy, 30(4), 685-691. http://dx.doi.org/10.1037/0033-3204.30.4.685

Burke, P. J., \& Stets, J. E. (2009). Identity theory. New York: Oxford University Press. http://dx.doi.org/10.1093/acprof:oso/9780195388275.001.0001

Clandinin, D. J., Downey, D. A., \& Huber, J. (2009). Attending to changing landscapes: Shaping the interwoven identities of teachers and teacher educators. Asia-Pacific Journal of Teacher Education, 37(2), 141-154.

http://dx.doi.org/10.1080/13598660902806316

Cooper, K., \& Olson, M. R. (1996). The multiple 'I's' of teacher identity. In M. Kompf, W. R. Bond, D. Dworet \& R. T. Boak (Eds.), Changing research and practice: Teachers' professionalism, identities and knowledge (pp. 78-89). London, Washington: The Falmer Press.

Danielewicz, J. (2001). Teaching selves: Identity, pedagogy and teacher education. Albany: University of New York Press.

Darling-Hammond, L., \& Snyder, J. (2000). Authentic assessment of teaching in context. Teaching and Teacher Education, 16(5), 523-545. http://dx.doi.org/10.1016/S0742-051X(00)00015-9

Day, C. (2002). School reform and transitions in teacher professionalism and identity. International Journal of Educational Research, 37(8), 677-692. http://dx.doi.org/10.1016/S0883-0355(03)00065-X

Feiman-Nemser, S., \& Floden, R. E. (1986). The cultures of teaching. In M. Wittrock(Ed.), Handbook of research on teaching (3rd ed.) (pp. 505-526). New York: Macmillan.

Grossman, P., \& McDonald, M. (2008). Back to the future: Directions for research in teaching and teacher education. American Educational Research Journal, 45(1), 184205. http://dx.doi.org/10.3102/0002831207312906

Hermans, H. J. M. (2001). The dialogical self: Towards a theory of personal and cultural positioning. Culture and Psychology, 7(3), 243-281. http://dx.doi.org/10.1177/1354067X0173001

Hermans, H. J. M., \& Hermans-Konopka, A. (2010). Dialogical self theory: Positioning and counter-positioning in a globalizing society. Cambridge: Cambridge University Press. http://dx.doi.org/10.1017/CBO9780511712142

Kelchtermans, G. (2009). Who I am in how I teach is the message: Self-understanding, vulnerability and reflection. Teachers and Teaching: Theory and Practice, 15(2), 257-272. http://dx.doi.org/10.1080/13540600902875332

Korthagen, F. (2001). Linking practice and theory: The pedagogy of realistic teacher education. Paper presented at the Annual Meeting of the American Educational Research Association, Seattle.

Korthagen, F., \& Vasalos, A. (2005). Levels in reflection: Core reflection as a means to enhance professional growth. Teachers and Teaching: Theory and Practice, 11(1), 47-71. http://dx.doi.org/10.1080/1354060042000337093 
Krull, E., Oras, K., \& Sisask, S. (2007). Differences in teachers' comments on classroom events as indicators of their professional development. Teaching and Teacher Education, 23(7), 1038-1050. http://dx.doi.org/10.1016/j.tate.2006.02.001

Kullasepp, K. (2008). Dialogical becoming. Professional identity construction of psychology students. (Doctoral Dissertation). Tallinn University Press, Tallinn.

Leijen, Ä., \& Kullasepp, K. (2013a). All roads lead to Rome: Developmental trajectories of student teachers' professional and personal identity development. Journal of Constructivist Psychology, 26(2), 104-114.

http://dx.doi.org/10.1080/10720537.2013.759023

Leijen, Ä., \& Kullasepp, K. (2013b). Unlocking the potential of conflicts: A pilot study of professional identity development facilitation during initial teacher education. International Journal of Dialogical Science, 7(1), 67-86.

Ligorio, M. B. (2011). The dialogical self and educational research: A fruitful relationship. In H. Hermans \& T. Gieser (Eds.), Handbook of the dialogical self theory (pp. 439-453). Cambridge: Cambridge University Press.

http://dx.doi.org/10.1017/CBO9781139030434.030

Löfström, E., Poom-Valickis, K., Hannula, M., \& Mathews, S. (2010). Supporting emerging teacher identities: Can we identify teacher potential among students? European Journal of Teacher Education, 33(2), 167-184.

http://dx.doi.org/10.1080/02619761003631831

Meijer, P. C. (2010). The teacher education knowledge base: Experienced teachers' craft knowledge. In E. Baker, P. Peterson \& B. McGaw (Eds.), International Encyclopedia of Education (3rd ed.) (Vol. 7, pp. 642-649). Oxford: Elsevier. http://dx.doi.org/10.1016/B978-0-08-044894-7.00639-4

Pillen, M. T., Den Brok, P. J., \& Beijaard, D. (2013). Profiles and change in beginning teachers' professional identity tensions. Teaching and Teacher Education, 34, 86-97. http://dx.doi.org/10.1016/j.tate.2013.04.003

Symonds, P. M. (1947). The sentence completion task as a projective technique. Journal of Abnormal and Social Psychology, 42(3), 320-329. http://dx.doi.org/10.1037/h0054808

Timoštšuk, I., \& Ugaste, A. (2010). Student teachers' professional identity. Teaching and Teacher Education, 26(8), 1563-1570. http://dx.doi.org/10.1016/j.tate.2010.06.008

Timoštsuk, I., \& Ugaste, A. (2012). The role of emotions in student teachers' professional identity. European Journal of Teacher Education, 35(4), 421-433. http://dx.doi.org/10.1080/02619768.2012.662637

Valsiner, J. (2001). Comparative study of human cultural development. Madrid: Fundación Infancia y Aprendizaje.

Valsiner, J. (2007). Culture in minds and societies. New Delhi: Sage.

Valsiner,J.,\&Rosa,A.(2007).TheCambridgehandbookofsocioculturalpsychology. Cambridge: Cambridge University Press. http://dx.doi.org/10.1017/CBO9780511611162

Van Zandt, C. E. (1990). Professionalism: A matter of personal initiative. Journal of Counseling and Development, 68(3), 243-245. http://dx.doi.org/10.1002/j.1556-6676.1990.tb01367.x

Von Eye, A. (1990). Introduction to configural frequency analyses: The search for types and antitypes in cross-classifications. Cambridge: Cambridge University Press. 


\section{Lisa 1}

1. Kui õpetaja on dilemma ees, kas õpilase poolt temale usaldatud informatsiooni teistele õpetajatele avaldada või mitte, siis ta tunneb ennast

kuna

2. Kui õpetaja ei suuda pikka aega õpilase kodustest probleemidest distantseeruda, siis ta tunneb kuna

3. Kui õpetajal palutakse õpilasele töövälisel ajal õpiabi osutada, siis õpetaja tunneb kuna

4. Kui õpetaja sõber palub õpetajat, et ta võtaks tema lapse huviringi, kus on kohad juba täis, siis ta tunneb kuna

5. Kui õpetaja mõistab, et ta ei suuda õpilasele aine olulist teemat arusaadavaks teha, siis ta tunneb kuna

6. Kui õpetaja peab ürituse organiseerima kolleegiga, kes talle ei meeldi, siis õpetaja tunneb kuna

7. Kui õpetaja peab tunnis käsitlema teemasid, mis talle huvi ei paku, siis ta tunneb , kuna

8. Kui õpetaja peab suhtlema lapsevanemaga, kes on väga ebameeldiv, siis ta tunneb , kuna

9. Kui õpetaja peab töötama õpilasega, kellel puudub õpihuvi, siis ta tunneb , kuna 


\title{
Investigating the internalization of professional role expectations among pre-service teachers
}

\author{
Äli Leijen ${ }^{\text {ab1 }}$, Katrin Kullasepp ${ }^{c}$, Aivar Ots ${ }^{\text {ac }}$ \\ ${ }^{a}$ University of Tartu, Institute of Education \\ ${ }^{\mathrm{b}}$ University of Tartu, Viljandi Culture Academy \\ ${ }^{\text {c }}$ University of Tallinn, Institute of Psychology
}

\section{SUMMARY}

Several scholars of teacher education (see for example Beijaard, 1995; Kelchtermans, 2009; Korthagen \& Vasalos, 2005) have pointed out that student teachers need to explore their identity, given that teachers' sense of their professional identity manifests itself in job satisfaction, occupational commitment, self-efficacy and changes in levels of motivation (Day, 2002). Several recent studies on teacher identity development (see e.g. Akkerman \& Meijer, 2011; Leijen \& Kullasepp, 2013a) have argued for dialogical perspectives when seeking to understand how the personal and professional selves are being negotiated in the course of becoming a professional, and how to support this process. In the current study, we introduce a questionnaire that was developed to explore the formation of a teacher's professional identity. The questionnaire was developed based on the theoretical notions (see the following subsection) that relate to the abovementioned dialogical tradition.

\section{Dialogical becoming}

According to the socio-cultural approach, the psychological functioning of humans is shaped by constructive interactions between the individual and the surroundings by means of semiotically mediated cultural material. These dialogical relations result in the adaptation of existing meanings and in the creation of new meanings (Valsiner \& Rosa, 2007). The constant exchange of perceptual and semiotic material with the environment leads to the reconstruction of intra-psychological worlds (Valsiner, 2001).

The laminal model (Valsiner, 2001) describes the person-environment dialogue in terms of constructive processes of internalization/externalization. Internalization is the process of the analysis and synthesis of externally existing

Institute of Education, Faculty of Social Sciences and Education, University of Tartu, Salme 1a, 50103 Tartu, Estonia, ali.leijen@ut.ee 
semiotic material into an intra-personally different form. Externalization, a parallel and complementary process to internalization, is the process of the analysis of personal-cultural material during its transposition into the external environment that thereafter becomes modified.

The Dialogical Self theory (DST) (Hermans, 2001; Hermans \& HermansKonopka, 2010) was applied in this study to understand intra-psychological dynamics when assuming a professional role. DST conceives the self as a system that consists of relatively autonomous I-positions between which the self fluctuates. These I-positions have been shaped through different historical, institutional and social events. Thus, the migration of students into the new social-environment can be viewed as an experience that supports the formation of the new I-position (I as a professional). The emergence of I-positions can be due to any kind of professional practice (e.g. attending classes, the formal settings of the school practicum) but can also be formed by informal factors (e.g. expectations of friends). DST, therefore, makes it possible to explain the formation of an identity by focusing on the emergence of I-positions within the context of professional-institutional practices and their relationship to other I-positions.

Our study also relies on the standpoint that inherently inconsistent I-positions („I as myself” and „I as a professional”) create ambivalent conditions when internalizing a professional role into the self-system. The treatment of ambivalence in the study indicates processes with a different orientation in a whole (Abbey \& Valsiner, 2005). Consequently, ambivalence that emerges within the conditions of the co-existence of different I-positions is conceived of as a key factor in the process of the internalization of the professional role (Kullasepp, 2008).

Based on the theoretical framework outlined above, a test aiming to evaluate the dynamics of the internalization of a professional role in the course of solving ambivalent pedagogical dilemmas was developed. An empirical study was conducted to evaluate the properties of the developed questionnaire and to answer the following research questions:

1. What is the relationship between the emotional response to the ambivalence and presentation of professional positions in student answers?

2. What is the relationship between work and study experience and the presentation of professional positions in student answers?

Following the Dialogical Self Theory premise that conflicting voices cohere in a self through synthesizing and dialogical relations, it is expected that with the progress of studies and pedagogical experiences, how teachers handle the ambivalent conditions of entering the professional role shows more extensive elimination of tension and growing presentation of professional 
positions. The latter is supported by findings from a recent pilot study (Leijen \& Kullasepp, 2013a) showing that in comparison to others, student teachers who presented professional I-positions before and after pedagogical practice in a stable manner less often presented negative emotions as a reaction to the ambivalence.

\section{Method}

\section{Participants}

Data were collected over a period of two years, from 109 students, who followed different subject teacher curricula in one university. The sample consisted of 70 students (67\%) who had just started their studies, 16 students who had finished the first year of teacher education, and 18 students who had reached the mid-point of the second year of teacher education $(32 \%$ of the sample had study experience in a teacher education curriculum) - $54 \%$ of the sample had no teaching experience.

\section{Data collection}

A DDTC-Teacher (Double Direction Theme Completion-Teacher) questionnaire was developed in this study based on earlier versions of DDTC questionnaires (Kullasepp, 2008; Leijen \& Kullasepp, 2013a). A DDTC is an extended version of the traditional sentence completion task (Symonds, 1947) that provides the temporal profiles of the coordination of personal orientations and professional roles. The developed questionnaire consisted of nine dilemmas. The selection of dilemmas was based on finding a variety of ambivalent situations related to i) pupils, ii) subject matter, and iii) colleagues, parents and acquaintances. Typical situations were chosen that would activate the inner dialogue between „I as a person” and „I as a professional”. For example, in the case of a dilemma related to 'providing confidential information to third parties' the student was triggered to identify how she communicated about the tension between the professional role and personal ethics. Second, the student was invited to indicate how she solves ambivalent dilemmas - whether she presents a professional position or another position. The other eight dilemmas were: 'asked to teach a student after school hours', 'no place for a friend's child in an after-school group, 'thinking often about a student who has problems at home', 'working with an unpleasant colleague,' 'communicating with an unpleasant parent', 'teaching an uninteresting topic, 'having difficulties with teaching a very important topic to students', and 'teaching students who are not interested in learning. The relevance of the 
dilemmas was approved by two experienced teachers and a leading teacher educator.

\section{Data coding and analysis}

Firstly, communication about the tension between the I-positions was identified in the answers. Regarding the tension, two codes were distinguished: reporting negatively orientated tensions (coded as 1) and reporting nonnegative emotions (coded as 0 ). Secondly, professional role internalization was coded through presentations of professional I-positions (see Leijen \& Kullasepp, 2013a for further information) (coded as 1) and other answers (coded as 0). Eighty-one (81) randomly selected answers ( 9 student answers to 9 dilemmas) from the database were independently analysed by a second researcher to test for inter-rater reliability. This resulted in an inter-rater reliability score of 0.96 (Cohen's Kappa) regarding the communication of negative emotions, and 0.91 (Cohen's Kappa) regarding professional I-positions.

Chi-square tests and configurational frequency analysis (CFA) were used to explore relationships between variables.

\section{Major results and discussion}

The inner-reliability score for the questionnaire was modest (Cronbach $\alpha$ 0.65). However, considering the manner of coding and the sample size, we considered this sufficient in the current study. Additional data need to be collected in order to give a more precise estimation of the questionnaire properties.

To answer the first research question, a CFA was employed to compare the presentation of professional I-positions (PIP) with the presentation of a combination of PIP and the communication of negative emotions. The results revealed that, in accordance with the researchers' intentions, the ambivalent situations had commonly evoked tensions and negative emotions. In addition, the results showed that students with a higher PMP score had more commonly reported neutral or positive emotions in their answers. This finding provides some support for the propositions of the study as we expected that the internalisation of PMP decreases tensions and is therefore related to less frequent communication of negative emotions.

In order to answer the second research question, a series of Chi-square tests were used. In accordance with the propositions, we found that a higher level of work and study experience is related to the more frequent presentation 
of PIP. In separate analyses, a significant correlation appeared only between work experiences and PIP. Therefore, the results do not support an opinion where university- and theory-centred teacher education in itself would support the internalization of the professional role as also shown by other studies (e.g. Alsup, 2006; Danielewicz, 2001). Rather, the internalization could be supported by an integrated approach of practice and theoretical studies, as also shown by others (see e.g. Korthagen, 2001; Korthagen \& Vasalos, 2005).

The major limitation of the current study is the sample size; a higher number of students with work- and study experience needs to be included in a sample for future studies in order to verify and explore the results presented in the current study.

Keywords: teacher professional identity, pre-service teacher education, role internalization, subject teacher, Dialogical Self Theory, socio-cultural approach 